\title{
Penggunaan Kosanoge Melalui Media WhatsApp dalam Pembelajaran Bahasa Jepang Di SMK Kesehatan Sadewa Yogyakarta
}

\section{Implementation of Kosanoge through WhatsApp Media in Japanese Language Learning at SMK Kesehatan Sadewa Yogyakarta}

\author{
Mery Kharismawati ${ }^{*}$, Iffatu Masruro Al Hakimi ${ }^{2}$ \\ Universitas Gadjah Mada ${ }^{1}$ \\ MAN 3 Bantul $^{2}$ \\ mery.kharismawati@ugm.ac.id ${ }^{1}$
}

\begin{abstract}
This research is a quantitative descriptive study that will describe: (1) the conditions of learning Japanese online through WhatsApp Group (WAG) at SMK Kesehatan Sadewa Yogyakarta, and (2) the students' perceptions about the use of kosanoge. The Japanese language course was introduced at this school in 2020. As the Covid-19 pandemic since March 2020 has disrupted the educational activities at schools, the teaching and learning at SMK Kesehatan Sadewa, including Japanese, must be carried out online. WhatsApp Group (WAG) was chosen as a medium for interactive and useful online learning. In practice, students are introduced to the kosanoge vocabulary game which aims to increase the student's enthusiasm for learning. The data were taken from the results of observations of class activities and online surveys. The random sample shows that the students were happy with the implementation of the kosanoge, but some students had difficulties because they had not memorized hiragana. A further research needs to be conducted to determine the effect of teacher classroom actions taken to increase student interaction in a class by using kosanoge games.
\end{abstract}

Keywords: WhatsApp, kosanoge, Japanese online learning, SMK Kesehatan Sadewa.

\section{Intisari}

Penelitian ini merupakan penelitian deskriptif kuantitatif yang akan memaparkan: (1) kondisi pembelajaran bahasa Jepang secara daring melalui WhatsApp Group (WAG) di SMK Kesehatan Sadewa Yogyakarta, dan (2) persepsi siswa mengenai penggunaan kosanoge. Bahasa Jepang diperkenalkan di SMK ini pada tahun 2020. Karena pandemi Covid-19 sejak Maret 2020 telah mengganggu aktifitas akademik di sekolah, kegiatan pembelajaran di di SMK Kesehatan Sadewa, termasuk bahasa Jepang, harus dilaksanakan secara daring. WhatsApp Group (WAG) dipilih sebagai media untuk pembelajaran daring yang interaktif dan padat manfaat. Dalam pelaksanaannya siswa diperkenalkan pada permainan kosakata kosanoge yang bertujuan meningkatkan semangat belajar siswa. Data diambil dari hasil observasi kegiatan kelas dan survey online. Berdasarkan sampel acak, ditunjukkan bahwa siswa merasa senang dengan penerapan kosanoge, namun ada siswa yang kesulitan karena belum hafal hiragana. Perlu diadakan penelitian lebih lanjut untuk mengetahui efek dari tindakan kelas guru yang dilakukan untuk meningkatkan interaksi siswa di kelas dengan menggunakan game kosanoge.

Kata kunci: kosanoge, WhatsApp, pembelajaran daring bahasa Jepang, SMK Kesehatan Sadewa

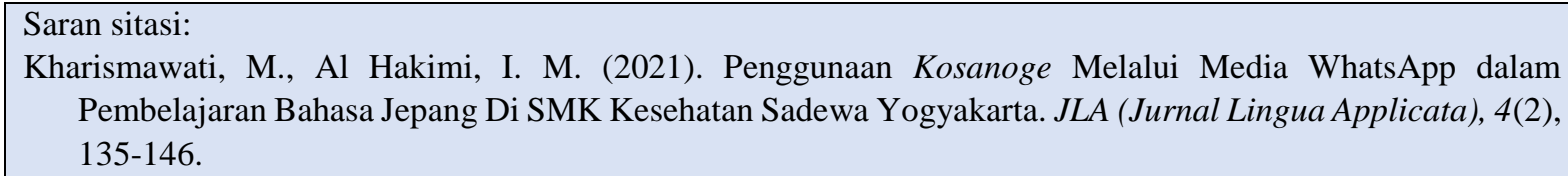

* Corresponding author

Copyright (C) 2021 The Author(s) This article is distributed under a 


\section{PENDAHULUAN}

Covid-19 merupakan sebutan virus yang mulai ramai diperbincangkan di daerah Wuhan, Tiongkok. Kemudian virus tersebut pertama terdeteksi di Indonesia, pada Maret 2020 (Debora, 2020). Sebagai wujud pencegahan merebaknya virus pada sektor pendidikan, pemerintah mengambil langkah dengan meniadakan pembelajaran tatap muka dan menggantinya dengan pembelajaran daring (dalam jaringan) atau online (Pemda DIY, 2020).

Salah satu sekolah yang terdampak kebijakan pemerintah ini adalah SMK Kesehatan Sadewa Yogyakarta. Sekolah ini memiliki dua jurusan yaitu Farmasi Klinis \& Komunitas dan Asisten Keperawatan. Pada SMK Kesehatan Sadewa ini terdapat mata pelajaran bahasa Jepang.

Berdasarkan pengamatan, sebagian besar peserta didik di SMK Kesehatan Sadewa terkendala dengan kepemilikan gawai dan jaringan. Pada pelaksanaan pembelajaran daring, semua guru di SMK Kesehatan Sadewa Yogyakarta, menggunakan Google Classroom (GC). GC merupakan fitur kelas milik perusahaan Google yang menyediakan platform pembelajaran online yang praktis, tetapi cukup memakan banyak kuota internet. Namun demikian menurut guru bahasa Jepang, pembelajaran dengan media ini dinilai kurang interaktif, karena terdapat kendala jaringan pada siswa. Selain itu, bahasa Jepang ini masih baru bagi mereka. Bahasa Jepang mulai ditawarkan pada siswa pada tahun 2020. Untuk mengatasi kurang efektifnya pembelajaran di GC, guru menambahkan pembelajaran melalui WhatsApp dengan membuat grup kelas (WAG) masing-masing jenjang dan jurusan. Kosakata dalam pembelajaran bahasa asing sangatlah penting, hal ini menjadi tantangan besar bagi seorang guru bahasa asing untuk dapat mengajarkan kosakata pada siswanya (Alqahtani, 2015). Sejalan dengan hal tersebut, pemelajar bahasa Jepang memerlukan proses yang cukup kompleks untuk dapat menginternalisasi kosakata bahasa Jepang yang direpresentasikan dalam huruf hiragana, katakana, dan kanji. Pemelajar character-based language seperti bahasa Jepang memerlukan usaha ekstra untuk menguasai kosakata, berbeda dengan bahasa asing lainnya (Yi, 2014).

Menghadapi masa pandemi yang mengharuskan pertemuan daring ini, guru perlu berinovasi mencari cara agar pembelajaran tetap berjalan dengan lancar. Tidak mudah bagi peserta didik untuk mengingat kosakata apalagi kosakata tersebut ditulis dengan huruf hiragana. Oleh karena itu, dalam pembelajaran bahasa Jepang di SMK Kesehatan Sadewa, digunakan sebuah metode untuk mengajarkan kosakata serta membantu peserta didik mengingat kosakata, metode ini memanfaatkan model pembelajaran permainan kosanoge (kotoba o sagasu no geети). Kosanoge sebenarnya adalah permainan mencari kosakata dalam kotak berisi huruf-huruf yang acak. Kosakata dapat ditemukan dengan mencari dari lajur mendatar, menurun, maupun menyilang. Permainan ini juga dikenal dengan sebutan 
word search. Pemberian nama kosanoge ditujukan supaya siswa pemelajar bahasa Jepang lebih bersemangat mempelajari kosakata bahasa Jepang. Hal ini karena permainan disesuaikan bahasa yang sedang dipelajari, dan menggunakan nama dari bahasa Jepang. Dengan kosanoge, siswa diharapkan dapat menemukan kosakata dalam tabel huruf acak sehingga terbiasa dengan kosakata bahasa Jepang yang ditulis dalam huruf hiragana.

Penelitian ini akan membahas dua hal, yaitu pertama: memaparkan hasil praktik pembelajaran bahasa Jepang secara daring dengan media WAG sebagai pembelajaran bahasa Jepang perdana di SMK Kesehatan Sadewa. Kedua, menjelaskan persepsi siswa terhadap pembelajaran bahasa Jepang secara daring di SMK Kesehatan Sadewa menggunakan metode permainan kosanoge.

Adapun penelitian lain yang membahas penggunaan aplikasi WhatsApp (WA) adalah (Afnibar \& Fajhriani, 2020). Menurutnya sebanyak $73.60 \%$ mahasiswa UIN Imam Bonjol Padang menganggap bahwa WA memudahkan untuk berkomunikasi, dan lebih menunjang kegiatan belajar dibandingkan dengan media lainnya. Penelitian lain menyebutkan bahwa penggunaan WAG dalam pembelajaran bahasa Inggris menunjukkan efektifitas yang tinggi pada mahasiswa Universitas Muhamadiyah Surabaya. Penelitian kualitatif ini memaparkan bahwa mahasiswa antusias belajar bahasa Inggris dengan berbagai fitur pada media WA dan menunjukkan peningkatan kualitas belajar (Wijaya, 2018).

Penelitian tentang metode permainan dalam pembelajaran kosakata bahasa Jepang telah dilakukan oleh Afifah dan Fanani (2018). Penelitian ini menjelaskan tentang penggunaan permainan Dokoni Karuta untuk membantu pemahaman kosakata siswa SMA I Puri Mojokerto. Permainan ini menggunakan instruksi sederhana sesuai bab yang sedang dipelajari. Instruksi ditulis pada kartu karuta, meniru permainan karuta asli yang memanfaatkan puisi Jepang. Hasil penelitian menunjukkan bahwa metode ini efektif bagi pemahaman bab 6 buku Nihongo Kira Kira. Selanjutnya, Kharlina dkk. (2014) membahas penggunaan metode Mystery Bag pada pembelajaran kosakata. Guru memberikan kantong berisi-benda benda yang pelafalan bahasa Jepangnya telah dipelajari sebelumnya. Setiap siswa harus mengeluarkan benda dari dalam kantong sambil menyebutkan nama benda tersebut dalam bahasa Jepang. Metode ini membuat peserta didik tertantang untuk menghafalkan kosakata benda yang ada dalam kantong (mystery bag) dalam bahasa Jepang.

\section{METODE PENELITIAN}

Penelitian ini merupakan pemaparan dari data observasi kegiatan kelas dan survey online mengenai persepsi siswa pada permainan kosanoge di pelajaran bahasa Jepang di SMK Kesehatan Sadewa Yogyakarta yang dilakukan secara daring 
pada tanggal 6-12 Desember 2020 dengan media WAG. Data dipaparkan menggunakan metode deskriptif kuantitatif untuk menginterpretasikan tanggapan siswa mengenai pemanfaatan game kosanoge yang diberikan di kelas online dengan media WhatsApp. Materi yang diberikan dalam pembelajaran adalah bagian salam dalam bahasa Jepang (aisatsu).

Untuk mendapatkan respons siswa mata pelajaran bahasa Jepang di SMK Kesehatan Sadewa, dibagikan kuesioner dengan menerapkan sistem random sampling dari total 106 peserta didik dari enam kelas. Sistem random sampling atau sampel acak menurut Sugiono (2016) dilakukan tanpa melihat strata dan kesamaan dalam populasi. Hal ini dilakukan apabila anggota populasi dianggap homogen. Dalam penelitian ini, populasi dianggap homogen, karena semua siswa dari berbagai kelompok kelas mendapatkan materi yang sama. Kuesioner berbentuk skala likert dengan pilihan jawaban Sangat Setuju (SS), Setuju, (S), Ragu-Ragu (RG), Tidak Setuju (TS), dan Sangat Tidak Setuju (STS) (Darmadi, 2011). Respons yang diolah berasal dari dari 47 siswa dengan rincian sebagai berikut: 4 orang kelas XI Asisten Keperawatan Moyudan, 17 orang kelas XII Asisten Keperawatan Moyudan, 3 siswa kelas X Farmasi Klinis \& Komunitas Moyudan, 9 orang kelas XI Farmasi Klinis \& Komunitas Babarsari, 10 orang kelas XII Farmasi Klinis \& Komunitas Moyudan.

\section{HASIL DAN PEMBAHASAN}

Pelajaran bahasa

Jepang diperkenalkan di SMK Kesehatan Sadewa karena terdapat alumni SMK Kesehatan Sadewa yang belajar di LPK (Lembaga Pelatihan Kerja) dan kemudian bekerja di Jepang sebagai perawat setelah lulus. Kepala Sekolah SMK Kesehatan Sadewa, Drs. Harminto, M.M menjelaskan bahwa mata pelajaran bahasa Jepang ini juga ditujukan agar siswa yang ingin bekerja di Jepang tidak perlu belajar bahasa Jepang dasar lagi ketika masuk di LPK. Selain itu, dengan adanya pembelajaran bahasa Jepang, SMK Kesehatan Sadewa diharapkan dapat menjalin kerjasama dengan LPK atau kampus-kampus yang memiliki jurusan Bahasa Jepang.

$$
\text { Pembelajaran bahasa Jepang }
$$

memerlukan interaksi yang intens antara guru dan peserta didik, yang biasa diperoleh melalui tatap muka secara langsung dalam durasi tertentu. Sementara itu, pergeseran dari metode pembelajaran tatap muka langsung (luring/luar jaringan) ke pembelajaran daring (dalam jaringan) menjadi tantangan tersendiri bagi seorang guru. Selain persiapan materi, seorang guru juga harus memikirkan metode yang bisa diperkenalkan pada siswa untuk digunakan pada saat belajar mandiri. Metode pembelajaran bahasa Jepang di masa pandemi mengalami perubahan drastis dari luring ke daring. Kelas bahasa Jepang yang biasanya dilaksanakan dengan interaksi langsung dan dengan beragam permainan di kelas, kini harus dilakukan dengan media 
laptop, komputer, atau ponsel, yang membatasi waktu, dan media yang bisa digunakan. Belum lagi kendala jaringan internet yang dialami sebagaian besar siswa. Hal ini membuat guru melakukan penyesuaian dari penggunaan media GC ke penggunaan WAG. Penyesuaian ini dilakukan setelah menimbang berbagai keluhan siswa terkait sinyal dan ketersediaan gawai.

WhatsApp dianggap sebagai media yang paling terjangkau, akrab dengan siswa, dan tidak terlalu terkendala jaringan internet. Selain itu pembelajaran kelas dengan WAG dapat dilakukan dengan interaktif karena siswa telah mahir menggunakannya dalam komunikasi sehari-hari, sehingga kelas aktif dengan kegiatan tanya jawab (engagement-nya tinggi). Menurut Hartono (dalam Afnibar \& Fajhriani, 2020) WA merupakan aplikasi pesan lintas platform yang memungkinkan penggunanya bertukar pesan tanpa biaya SMS. Hal ini karena WA menggunakan paket data internet yang sama untuk email, penelusuran di internet, dan lain-lain. WA memiliki berbagai fitur untuk berbagi media seperti foto, suara, tautan, yang dapat dilakukan dengan cepat dan mudah. Untuk itu guru bahasa Jepang memanfaatkan WA dengan membuat WhatsApp Group (WAG) untuk 6 kelas yang belajar bahasa Jepang untuk pertama kalinya di SMK Kesehatan Sadewa. Adapun praktik pengajaran dengan media WAG tersebut dapat dilihat dalam tahapan pembelajaran daring yang dilakukan guru SMK Kesehatan Sadewa.

\section{Pembelajaran Bahasa Jepang Dengan Media WAG}

a. Pembukaan

Kegiatan pendahuluan melalui media WAG kelas dilakukan supaya siswa dapat mempersiapkan diri dan dapat berkonsentrasi dalam pembelajaran. Karena tidak dapat bertatap muka secara langsung, guru menilai keaktifan siswa berdasarkan keaktifannya merespon pesan dari guru di WAG. Berdasarkan observasi, pada bagian pembukaan ini dibutuhkan kreativitas guru dalam membangkitkan semangat belajar siswa. Adapun tahapan yang dilakukan guru adalah sebagai berikut:

1) Guru menyapa peserta didik dengan ucapan salam.

2) Jawaban salam dari guru menjadi presensi (kehadiran) peserta didik.

3) Guru mengajak peserta didik untuk berdoa bersama sebelum mengawali kegiatan pembelajaran.

4) Guru menanyakan tanggapan dari pembelajaran sebelumnya.

5) Peserta didik merespon pertanyaan dari guru tentang pembelajaran sebelumnya.

6) Guru mengapresiasi respons dari siswa dengan ucapan pujian dan penyemangat. Guru juga menyapa siswa yang belum menjawab supaya tertarik untuk menjawab.

7) Peserta didik menyimak informasi dari guru tentang kompetensi dan tujuan pembelajaran yang akan dicapai dan manfaatnya dalam kehidupan seharihari. 
8) Peserta didik merespon secara aktif informasi tentang hal-hal yang akan dipelajari termasuk metode dan media, langkah pembelajaran, dan penilaian pembelajaran.

\section{b. Inti Materi}

Pada bagian ini, guru menjelaskan bagian-bagian materi salam dalam bahasa Jepang (aisatsu) dengan media voice note (VN) dan foto. Pada bagian ini pula kemudian guru mengecek pemahaman kosakata siswa sekaligus ingatan akan huruf hiragana siswa dengan permainan kosanoge. Bagian kedua dari pembelajaran dengan WAG ini memakan waktu cukup lama dan terkadang pesan dari guru tenggelam di antara respon siswa yang semuanya ingin aktif menjawab pertanyaan. Guru perlu menerapkan pengaturan waktu dan kelas supaya tidak ada materi yang terlewat, maupun jawaban siswa yang terabaikan. Adapun tahapan pada inti materi adalah sebagai berikut:

1) Peserta didik mengamati gambar yang diberikan guru.

2) Peserta didik mengidentifikasi dan memahami penyebutan kosakata dalam bahasa Jepang.

3) Guru menanyakan ke peserta didik tentang pemahaman kosakata yang sudah disampaikan guru.

4) Peserta didik merespon pertanyaan guru.

5) Guru menyuruh peserta didik melafalkan kosakata yang sudah ditunjukkan, peserta didik merekam melalui VN, kemudian mengirim ke WAG.

6) Guru memberikan kosanoge pada siswa untuk mengingatkan kosakata yang sudah dipelajari dan melatih mengingat huruf hiragana.

7) Peserta didik merespon permainan kosakata yang diberikan oleh guru dan menjawabnya.

8) Guru memberikan apresiasi kepada peserta didik yang aktif dan memberi motivasi untuk peserta lainnya.

\section{c. Penutup}

Bagian penutup tidak kalah penting dari bagian pembukaan dan inti materi kelas Bahasa Jepang menggunakan WAG. Pada bagian ini pun guru harus dapat mengelola waktu dengan baik dan dapat mengelola keriuhan lontaran respon dari siswa, tanpa mengabaikan jawaban/ respon siswa. Sedapat mungkin guru harus memastikan terdapat ringkasan materi/capaian pembelajaran pada hari tersebut, menjelaskan tugas yang harus dikerjakan siswa, dan juga memberikan ucapan penyemangat yang membuat siswa bersemangat menunggu pertemuan berikutnya. Berikut ini adalah tahapan yang dilakukan di bagian penutup.

1) Guru bersama peserta didik melakukan refleksi tentang kegiatan pembelajaran.

2) Guru memberikan penguatan kepada peserta didik untuk tetap semangat dan mengikuti pembelajaran.

3) Guru mengajak peserta didik berdoa untuk mengakhiri kegiatan pembelajaran. 
4) Guru menutup kegiatan pembelajaran dengan mengucapkan salam.

\section{Kosanoge}

\section{a. Permainan Kosanoge}

Materi yang dibahas di kelas daring dalam penelitian ini adalah mengenai salam dalam bahasa Jepang (aisatsu). Adapun kompetensi dasar yang harus dicapai adalah sebagai berikut: (1) menentukan ungkapan sapaan, berpamitan, mengucapkan terima kasih, meminta maaf, meminta izin, instruksi, (2) cara merespon ungkapan tersebut pada teks transaksional lisan dan tulis, dengan memperhatikan unsur kebahasaan, struktur teks, dan unsur budaya sesuai konteks penggunaannya. Untuk menunjang pemahaman siswa pada kosakata bahasa Jepang yang muncul pada bab ini, guru menerapkan strategi permainan kosakata dengan kosanoge.

Kosanoge kepanjangan dari kotoba o sagasu no geemu. Kosanoge merupakan game mencari kosakata pada kolom-kolom yang berisi huruf-huruf hiragana. Peserta didik harus mencari kosakata dengan melingkari huruf-huruf yang membentuk kosakata yang ada pada instruksi. Setelah mencari kosakata, peserta didik diminta menulis cara baca dan menyebutkan terjemahan dari kosakata yang sudah dicari. Tujuan dari game ini adalah untuk mengingat huruf hiragana serta kosakata yang sudah diajarkan oleh guru. Selain itu, peserta didik dilatih untuk tangkas dan cepat untuk mencari kosakata yang ada pada daftar pencarian. Di bawah ini adalah urutan pelaksanaan permainan kosanoge.
1) Guru memberi intruksi kepada pesera didik di WAG masing-masing kelas.

2) Mengirim gambar kosanoge ke WAG masing-masing kelas.

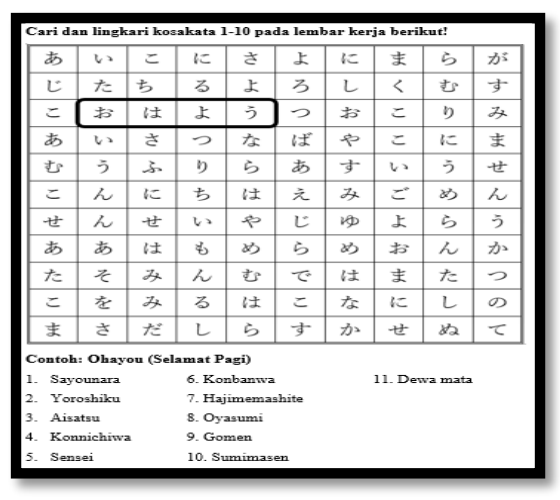

Gambar 1. Contoh Permainan Kosanoge

3) Bertanya kepada peserta didik apakah mereka sudah paham dengan aturan main kosanoge. Guru memastikan bahwa seluruh peserta didik sudah memahami dengan baik aturan permainan kosanoge.

4) Memberikan waktu pada peserta didik selama 10 menit untuk mencari kosakata.

5) Guru menyuruh peserta didik mengirim jawabannya di grup.

6) Setelah itu guru menyuruh mengartikan jawaban yang diperoleh peserta didik.

7) Peserta didik yang paling cepat, tepat, dan paling banyak menemukan kosakata, akan mendapatkan reward dari guru.

\section{b. Tanggapan Peserta Didik terhadap Kosanoge}

Setelah selama satu minggu kosanoge diperkenalkan kepada peserta 
didik, angket mengenai pembelajaran kosakata bahasa Jepang disebarkan pada siswa. Gambar 2 menggambarkan persentase peserta didik yang menjawab angket. Dari angket yang sudah diberikan ke peserta didik pada enam kelas (X Asisten Keperawatan Moyudan, XI Asisten Keperawatan Moyudan, XII Asisten Keperawatan Moyudan, X Farmasi Klinis \& Komunitas Moyudan, XI Farmasi Klinis \& Komunitas Babarsari, dan XII Farmasi Klinis \& Komunitas Moyudan) terdapat 47 peserta didik yang memberikan tanggapan. Gambar 3 menunjukkan tingkat kepuasan siswa pada penggunaan kosanoge dalam pembelajaran kosakata bahasa Jepang. Adapun indeks yang diperoleh dari jawaban soal ini adalah $66 \%$ berada dalam rentang interval nilai "setuju" yang bisa dilihat pada tabel 2. Dapat disimpulkan bahwa peserta didik mendapatkan kepuasan dalam menggunakan metode kosanoge dalam pembelajaran salam bahasa Jepang dengan media WAG.

\section{Kelas}

47 responses

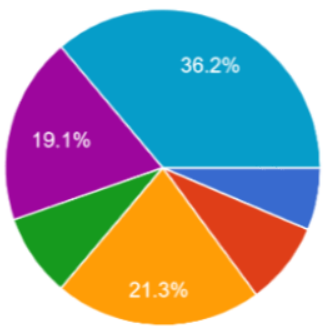

X Farmasi Klinis \& Komunitas Moyudan

XI Farmasi Klinis \& Komunitas Babarsari

XII Farmasi Klinis \& Komunitas

Moyudan

X Asisten Keperawatan Moyudan

XI Asisten Keperawatan Moyudan

XII Asisten Keperawatan Moyudan

Gambar 2. Persentase Peserta Didik yang Memberi Tanggapan Tentang Penggunaan Kosanoge

Bagaimana tingkat kepuasan anda untuk penggunaan "kosanoge" dalam pembelajaran bahasa Jepang?

47 responses

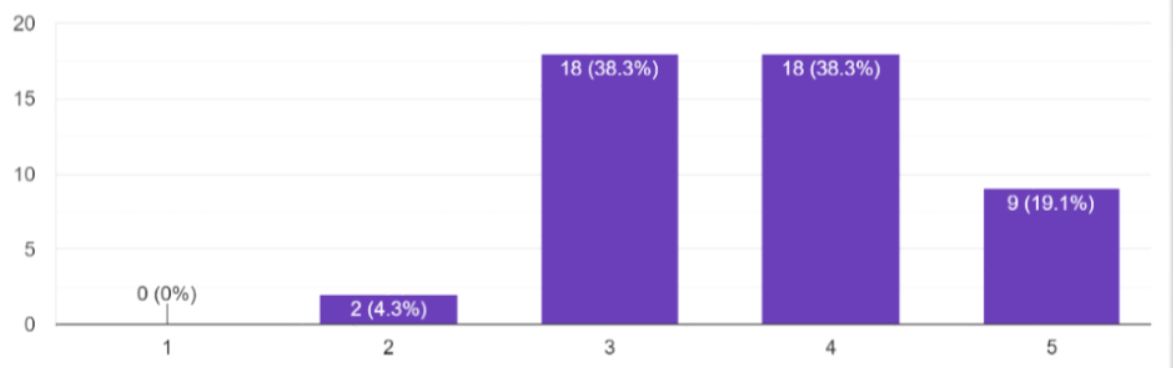

Gambar 3. Tingkat Kepuasan terhadap Penggunaan Kosanoge dalam pembelajaran Kosakata Bahasa Jepang 
Tabel 1. Total Skor Tingkat Kepuasan

\begin{tabular}{lccc}
\hline Jawaban & Nilai & $\begin{array}{c}\text { Jawaban } \\
\text { responden }\end{array}$ & $\begin{array}{c}\text { Skor } \\
\text { jawaban }\end{array}$ \\
\hline SS & 5 & 9 orang & 45 \\
S & 4 & 18 orang & 54 \\
RG & 3 & 18 orang & 54 \\
TS & 2 & 2 orang & 4 \\
STS & 1 & 0 & 0 \\
& & Total & 157 \\
\hline
\end{tabular}

Sumber : (Darmadi, 2011)

Skor Maksimal adalah:

jumlah responden $\mathrm{x}$ skor tertinggi $=234$

Skor Minimal adalah :

jumlah responden $\mathrm{x}$ skor terendah $=47$

Dengan demikian indeks jawaban adalah

Skor total:

skor maksimal x 100\% = Indeks jawaban

$$
(157: 235) \times 100 \%=66 \%
$$

Sumber : (Darmadi, 2011)

Tabel 2. Rentang Nilai

\begin{tabular}{ll}
\hline Persentase & Interpretasi \\
\hline $0 \%-19,99 \%$ & Sangat Tidak Setuju \\
$20 \%-39,99 \%$ & Tidak Setuju \\
$40 \%-59,99 \%$ & Ragu \\
$60 \%-79,99 \%$ & Setuju \\
$80 \%-100 \%$ & Sangat Setuju \\
\hline
\end{tabular}

Sumber : (Darmadi, 2011)
Peserta didik juga ditanya mengenai derajat kemanfaatan dari metode kosanoge dalam pembelajaran kosakata. Hasil dari angket online ditunjukkan pada gambar 4 .

Hasil perhitungan menunjukkan bahwa peserta didik merasakan manfaat positif dari metode kosanoge. Hal ini dibuktikan dengan indeks sebesar 79,1\% yang berada pada rentang nilai "setuju" (lihat tabel 2). Adapun perhitungannya adalah sebagai berikut:

\section{Skor total:}

skor maksimal x 100\% = Indeks jawaban

$$
(186: 235) \times 100 \%=79,1 \%
$$

Sumber : (Darmadi, 2011)

Tabel 3. Total Skor Tingkat Kemanfaatan

\begin{tabular}{lccc}
\multicolumn{4}{c}{ Kosanoge } \\
\hline Jawaban & Nilai & $\begin{array}{c}\text { Jawaban } \\
\text { responden }\end{array}$ & $\begin{array}{c}\text { Skor } \\
\text { jawaban }\end{array}$ \\
\hline SS & 5 & 16 orang & 8 \\
S & 4 & 16 orang & 64 \\
RG & 3 & 12 orang & 36 \\
TS & 2 & 3 orang & 6 \\
STS & 1 & 0 & 0 \\
& & Total & 186 \\
\hline
\end{tabular}

Sumber : (Darmadi, 2011)

Apakah penggunaan "kosanoge" berperan dalam membantu anda belajar kosakata bahasa Jepang?

47 responses

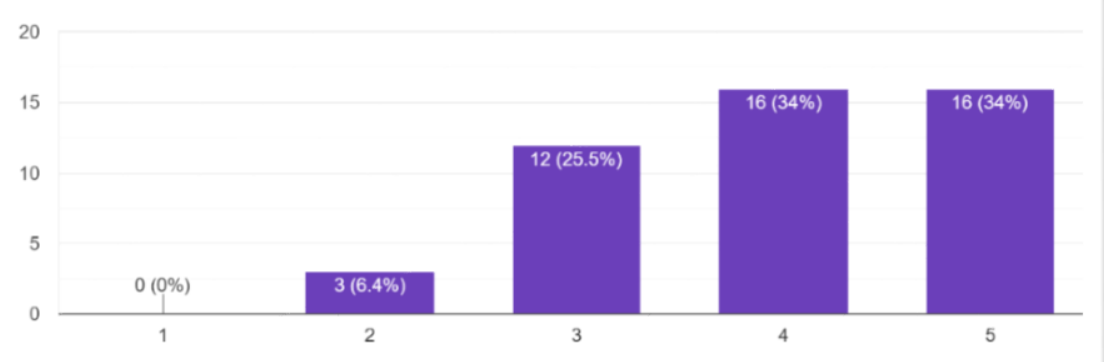

Gambar 4. Tingkat Manfaat Kosanoge Dalam Pembelajaran Kosakata 
Dalam praktik di kelas daring, guru memancing perhatian siswa dengan permainan kosanoge. Dalam sekali permainan kosanoge terdapat 10 kosakata yang harus diidentifikasi oleh siswa. Dengan kosanoge, guru mengamati bahwa siswa tertarik untuk berlomba menemukan kosakata yang sudah pernah dipelajari.

Pada angket peserta didik memberikan beberapa ulasan mengenai kosanoge. Dari jawaban para siswa dapat dipahami bahwa kosanoge bisa terus digunakan sebagai media pembelajaran online di sekolah. Dengan penggunaan kosanoge, peserta didik tertarik untuk mempelajari kosakata bahasa Jepang. Selain itu, kosanoge sangat membantu untuk menghafal huruf-huruf Jepang. Pada siswa yang belajar bahasa Jepang dasar, tentu memiliki tugas untuk menghafal huruf hiragana dan katakana. Kosanoge membantu siswa untuk mengasah hafalan huruf-huruf ini dan juga melatih ingatan siswa pada arti kosakata yang ditemukan. Dari segi humor, siswa terkadang melontarkan jawaban berupa susunan hiragana yang tidak memiliki arti sama sekali. Jika ada jawaban salah, maka guru akan memberikan koreksi pada siswa dan menyemangati siswa supaya tidak malu menjawab pada kesempatan berikutnya.

Selain berpendapat mengenai manfaat kosanoge, terdapat juga peserta didik yang berpendapat bahwa meskipun belajar menggunakan kosanoge menyenangkan, tetapi terasa sedikit rumit. Beberapa peserta didik juga menyarankan agar kosanoge perlu dibuat lebih menarik.
Peserta didik juga menyampaikan bahwa penggunaan kosanoge menuntut mereka hafal hiragana supaya bisa mencari kosakata.

\section{KESIMPULAN}

Penelitian ini menjelaskan proses pembelajaran bahasa Jepang dengan media WAG pada pembelajaran perdana bahasa Jepang di SMK Kesehatan Sadewa. Bahasa Jepang dipilih sebagai bahasa asing yang diajarkan di SMK Kesehatan Sadewa dengan tujuan mempersiapkan kebutuhan siswa yang ingin bekerja di Jepang. SMK Sadewa memperkenalkan bahasa Jepang mulai semester genap, yaitu pada bulan Juli tahun 2020. Pandemi Covid-19 yang melanda, membuat kelas bahasa Jepang dilaksanakan secara daring. Media WAG dipilih oleh guru bahasa Jepang sebagai pengganti platform pembelajaran GC. Hal ini dilakukan karena siswa mengalami kendala keterbatasan gawai dan jaringan internet untuk mengakses GC. Dalam pelaksanaannya, guru membuat WAG untuk masing-masing kelas, kemudian melaksanakan pembelajaran dengan 3 tahapan, yaitu pembukaan, inti materi, dan penutup.

Tahap pertama adalah pembukaan, di sini guru menyapa siswa dan mengingatkan materi yang telah diberikan sebelumnya. Permainan kosanoge digunakan pada bagian inti materi. Tujuannya untuk menggugah semangat siswa belajar bahasa Jepang, supaya tidak mengantuk, dan terbiasa dengan huruf hiragana. Kemudian pada inti materi, guru menjelaskan materi menggunakan berbagai 
media, seperti dokumen format MS Word, pdf, foto, dan voice note. Siswa juga diminta untuk mengumpulkan tugas berupa rekaman suara dan dokumen berisi jawaban soal. Kelas Bahasa Jepang daring di SMK Kesehatan Sadewa mendapatkan kesan yang baik dari para siswa yang ditunjukkan dengan antusiasme siswa pada saat pembelajaran berlangsung.

Dalam pelaksanaannya, guru memberikan permainan kosanoge. Berdasarkan angket tanggapan peserta didik terhadap penggunaan kosanoge dalam pembelajaran kosakata bahasa Jepang, peserta didik menganggap kosanoge cukup sesuai untuk digunakan dalam pembelajaran online dan membantu dalam pembelajaran kosakata bahasa Jepang. Selain itu, peserta didik juga merasa puas dengan penggunaan kosanoge. Meskipun demikian, masih perlu dilakukan inovasi pada pembelajaran bahasa Jepang secara daring di SMK Kesehatan Sadewa, mengingat masih dijumpai siswa yang merasa kesulitan memahami materi maupun penulisan hiragana.

\section{DAFTAR PUSTAKA}

Afifah, S. N., \& Fanani, U. Z. (2018). Pengaruh Penggunaan Media Permainan Dokoni Karuta Terhadap Penguasaan Kosakata Bahasa Jepang Bab 6 Buku "Nihongo Kira Kira" Siswa Kelas X SMAN 1 Puri Mojokerto Tahun Ajaran 2017 / 2018. Jurnal Mahasiswa Unesa, $1-9$.

Afnibar, A., \& Fajhriani, D. N. (2020). Pemanfaatan WhatsAPP sebagai Media
Komunikasi Kegiatan Belajar ( Studi terhadap Mahasiswa UIN Imam Bonjol Padang ). Al-Munir: Jurnal Komunikasi Dan Penyiaran Islam, 11, 70-83. https://ejournal.uinib.ac.id/jurnal/index. php/almunir/article/download/1501/112 2

Alqahtani, M. (2015). The importance of vocabulary in language learning and how to be taught. International Journal of Teaching and Education, III(3), 21-34. https://doi.org/10.20472/te.2015.3.3.002

Darmadi, H. (2011). Metode Penelitan Pendidikan. Penerbit Alfabeta.

Debora, Y. (2020). Riwayat Kasus Corona di Indonesia, dari Maret hingga September 2020 - Tirto.ID. https://tirto.id/riwayat-kasus-corona-diindonesia-dari-maret-hingga-september2020-f4d6

Kharlina, D. A., Basri, M. S., Budiani, D., Training, T., \& Faculty, E. (2014). Penerapan Permainan Mistery Bag Sebagai Strategi Pembelajaran Kosakata Benda Bahasa Jepang Pada SIwa Kelas XI Tahun Ajaran 2014 SMK Kansai Pekanbaru. Riau University.

Pemda DIY. (2020). Surat Edaran Pembelajaran Jarak Jauh bagi Anak Sekolah dalam rangka pencegahan COVID-19.pdf.

Sugiyono. (2016). Metode Penelitian Kuantitatif, Kualitatif dan $R \& D$. PT Alfabet.

Wijaya, A. (2018). Students ' Responses Toward the Use of Whatsapp in Learning. Journal of Teaching \& Learning English in Multicultural Contexts, 2(1), 46-55. 
JLA (Jurnal Lingua Applicata), Vol. 4 No. 2, 2021

Yi, H. (2014). Foreign Language Vocabulary Learning Strategies:

Patterns of use among college students

(Issue June). Auburn University. 